\title{
Heterosexism and the geographies of everyday life in Belfast, Northern Ireland ${ }^{\dagger}$
}

\author{
Rob Kitchin \\ Department of Geography and National Institute of Regional and Spatial Analysis, National \\ University of Ireland, Maynooth, County Kildare, Ireland; e-mail: Rob.Kitchin@may.ie
}

\section{Karen Lysaght}

National Institute of Regional and Spatial Analysis, National University of Ireland, Maynooth, County Kildare, Ireland; e-mail: Karen.Lysaght@may.ie

Received 31 January 2002; in revised form 23 August 2002

\begin{abstract}
In this paper we seek to extend work on the relationship between sexuality, space, and society by providing a nuanced geographical reading of the sexual production of space in Belfast, Northern Ireland. Utilising queer theory, we draw from interviews with thirty gay, lesbian, bisexual, and transgender individuals to illustrate how the discursive and material practices that shape the regulation, self-regulation, and resistance of heterosexism are spatially, temporally, and contextually uneven and unequal. Focusing on the spatial arenas of home, work, and social space we document how each space is produced and experienced in multiple ways, and managed using a variety of sociospatial strategies.
\end{abstract}

\section{Introduction}

Over the past decade or so, the examination of geographies of sexuality has developed as a vibrant topic of research. Empirical investigations have focused on a number of themes, including the spatial tactics used to create and sustain social networks (Valentine, 1993); the formation, nature, contestation, politicisation, and economic or social role of so-called 'gay' commercial (Binnie, 1995) and residential spaces (Adler and Brenner, 1992; Forrest, 1995; Knopp, 1995; Lauria and Knopp, 1985); the paradoxical relationship between safe 'gay ghettos' and homophobic violence (Moran et al, 2001; Myslik, 1996); issues of sexual citizenship (Bell and Binnie, 2000; Brown, 1997); and spatial strategies of resistance such as gay pride marches (Brickell, 2000; Davis, 1995). In general, this work has tended to focus on gay men, although there is a growing interest in lesbian geographies (see Bell and Valentine, 1995; Peake, 1993; Valentine, 2000). More recently attention has been paid to geographies of heterosexuality, in particular relating to sex work (Hubbard, 1999) and sex tourism (Law, 2000). This work by geographers has been accompanied by that of historians, sociologists, cultural theorists, political economists, and architects keen to explore the intersections between sexuality, space, and society (see Bailey, 1999; Beemyn, 1997; Betsky, 1997; Ingram et al, 1997; Leap, 1999; Patton and Sanchez-Eppler, 2000; Whittle, 1994). These studies have employed a diverse set of theoretical positions, including forms of psychoanalysis, poststructuralism, postmodernism, social constructivism, political economy, and so on, seeking in broad terms to develop what Keith and Pile (1993) have called a spatialised politics of identity (examining the geographies of power

$\dagger$ The work in this paper was undertaken as part of an Economic and Social Research Council funded project on 'Mapping the spaces of fear: the sociospatial processes of violence in Northern Ireland', award number L133251007. Part of the research was undertaken when both authors were based at Queen's University of Belfast.

- Corresponding author. 
as they relate to sexual dissidents ${ }^{(1)}$ ), and/or an identity politics of place (examining the sexual geographies of power that operate in particular spatial arenas).

Although diverse, these recent positions are generally united by nonessentialist conceptions of sexuality, in which the supposed natural links between sexuality, biology, and reproduction ${ }^{(2)}$ is uncoupled. Instead, sexuality is conceived as a social regulatory framework consisting of discursive and material practices that shape sociospatial meanings, behaviours, and experiences, wherein it is recognised that different sexualities and sexual acts have had varying cultural meanings at different times and in different places; how we view and understand sexuality is historically and spatially contingent, changing over time and space (see Foucault, 1978). Despite this adoption of theoretic positions that are potentially more sensitive to differences across individuals, space and time, Binnie and Valentine (1999) conclude in their overview of the subject that a "more critical treatment of the differences between sexual dissidents" is still lacking; many accounts, although sensitive to differences between groups, implicitly fail to differentiate internally (so for example, the experiences of lesbians or gay men are universalised, and thus analysis can slip into reductionism).

In this paper, we seek to answer Binnie and Valentine's (1999) call to develop more nuanced understandings of the geographies of sexuality through an in-depth examination of the varying forms, experiences, and consequences of homophobic intimidation and violence in Belfast, Northern Ireland. In doing so, we draw on queer theory to develop an analysis that recognises the multifaceted, uneven, and unequal ways in which heterosexist discourse and practice shapes the lives of sexual dissidents, allowing us to account for diversity within self-identified groups, operating within a range of city spaces.

\section{Queer theory, heterosexism, and space}

Queer theory, a theoretical position founded on poststructuralist ideas, posits that sexual identity is never fixed, but is always in a process of becoming (Jagose, 1996). As such, it critiques the notion of being able to draw coherent boundaries around sexual identities and instead contends that sexuality is a product of socialisation and a dynamic project of the self, so that sexual identities are established and maintained through repeated, stylised, and embodied performances (Butler, 1990; 1993). These performances are shaped by other aspects of identity (for example, race, disability, religion) and the social or political context in which they are performed (for example, social and legal regulation, and in our case sectarianism); at the same time the complex power geometries operating within and across communities of sexual dissidents are recognised. In other words, queer theory decouples sexual identification from sexual roles and sex acts, thus denaturalising sexual orientation and acknowledging that there are a multiplicity of sexualities that are fluid and contextual (Jagose, 1996). This view of sexuality recognises, for example, that people can engage in same-sex relations without necessarily identifying as being homosexual and that there are multiple understandings and experiences of gay identification. Here, the binary of heterosexual-homosexual is

(1) The term sexual dissidents refers to individuals who do not perform as 'good' heterosexuals, for example, gay men, lesbians, bisexuals, and heterosexuals who practise 'deviant' sexual acts such as sadomasochism, bondage, and so on (see, Rubin 1989). As such, 'sexual dissidents' are very heterogeneous in sexual identification.

(2) Wherein sexual orientation is understood as fixed-culturally independent, innate and objective. 
seen as a regulatory fiction, with the consequence that normative assumptions underpinning the 'naturalness' of heterosexuality are themselves merely fictions. (3)

As we discuss more thoroughly elsewhere, an extension of queer theory suggests that, given Valentine's (1993; 1996) argument that all space is sexed, all space is inherently queered and is only ever temporarily fixed as heterosexual (or homosexual for that matter). That is, the sexing of space is in a constant process of 'becoming', created through the (re)production of (sexual) discourse and practice. It thus follows that deconstructing such discourse and practice, and its resistance, allows us to start to understand the ways in which the sexing of space is constantly being brought into being and how such becoming is spatially and temporally contingent. This, in essence, was Foucault's (1978; 1984a; 1984b) project in his trilogy The History of Sexuality.

Foucault posited that people's identities are bought into being through discourses; that all social categories are discursively constructed. Subject identities are not given, but are created through representations, practices, and performances, with the placing of people into particular sexual categories dependent on the predominant discourse and power relations operating at any time. Through genealogical analysis of knowledge and practice at different sites at different times, Foucault illustrated how specific sexual identities were created through discourse; how distinctions between identities became regarded as logical, acceptable, and normal; and how they were policed and regulated through webs of disciplinary power.

Foucault (1978) termed the dominant sets of discourse about sexuality at any particular space-time a discursive regime. Here, we understand a discursive regime to be the interlocking sets of discourses by which institutions and communities wield power through a process of definition and exclusion, intelligibility and legitimacy. In other words, a discursive regime provides the justification for how places are sexed, and is used to legitimate discursive and material practices aimed at maintaining and regulating moral order and control. Foucault noted, however, that discursive regimes do not operate solely from the top downwards, but through microcircuits of power, the outcome of processes of regulation, self-regulation, and resistance. As such, sexual dissidents are not simply victims of the operations of power, but are produced by those same operations.

As shown by the work of Foucault, it is argued that in Western society today a discursive regime operates which reproduces heterosexuality as normal, natural, and 'good' (Rubin, 1989; Saraga, 1998) and homosexuality as deviant, unnatural, and immoral. As a number of analysts have noted, heteronormative social relations are reproduced and legitimated through a range of discursive and material practices. Such discursive practices range from political rhetoric, religious doctrine, medical theory, local and national legislation, censorship, sex education, and media-created moral panics. In turn, these discursive strategies create a climate of homonegativity and are used to legitimate material practices such as the denial of civil rights, denial of services (for example, obtaining life insurance or endowment mortgages), vandalising property, intimidation, abusive phone calls, and physical attacks. Combined, these practices explicitly aim to discipline sexual bodies, reinforcing boundaries between 'normal' heterosexual relations and supposedly 'abnormal' same-sex or deviant heterosexual relations (for example, bondage, sadomasochism, the use of sex workers). As we document

(3) It is important to note here that queer theory does not, however, deny that an individual can selfidentify with a category such as 'heterosexual', 'gay', or 'lesbian', or that this category is in itself meaningless for that individual, but it does recognise that this category is notional, contingent, and internally (by members) and externally (by nonmembers) contested. As such, it does recognise that the category is 'real' in the sense that people subscribe to its label, and thus it has significance, but also that the meaning of this category varies between these people and over time and space. 
below, such disciplinary practices can lead to marginalisation within, exclusion from, and selective use of, different spatial domains such as work, home, and leisure spaces, having profound effects on the sociospatial lives of sexual dissidents.

Importantly, though, we would argue that discursive and material expressions of heterosexism do not operate evenly or equally across sexual dissidents, with experiences of homophobic intimidation and violence varying by (and across) class, gender, race, religion (and so on), and also space, time, and context. Moreover, because heterosexism is always in a process of becoming, it is open to resistance, subversion, parody, and challenge. As such, the sociosexual landscape is made up of complex power geometries, subject to spatially uneven processes of regulation, self-regulation, and contestation. Consequently, the geographies experienced and produced by sexual dissidents are highly variable. Deconstructing the sexual landscape therefore requires a nuanced geographical reading that acknowledges the diversity of sexual dissidence and the unevenness and inequalities of any operating discursive regime, and extends well beyond a reductionist, universalistic account. In the rest of the paper we detail, in brief, discursive and material expressions of heterosexism in Belfast, and concentrate on the varied sociospatial consequences of heterosexism in relation to everyday life.

The data we analyse were generated as part of a larger project, funded by the Economic and Social Research Council, investigating how fear shapes the everyday lives of people living in Belfast and how this fear is managed both by residents of certain areas and by public officials and city managers. The principal focus of the wider project centred on how the discursive and material practices of sectarianism shaped city life. To complement and extend this main focus, we also sought to interview members of groups whose lives might be shaped by other fears, focusing in particular on the experiences of Belfast's sexual dissidents.

Data generation applied the same format as other parts of the project, consisting of in-depth interviews using an interview guide approach (see Kitchin and Tate, 2000). In total thirty sexual dissidents were formally interviewed: nineteen individual interviews, two in pairs, one large focus group of twelve-five of whom were individually interviewed at a later date, and two of whom took part in a smaller focus group of three. Interviews took place between June 2000 and August 2001; they lasted between three quarters of an hour and six hours, and all were taped and transcribed in full. The interviewees were self-identified as twenty gay men, eight lesbians, one bisexual woman, and one transgender. ${ }^{(4)}$ Ages varied between late teens and early seventies; the majority of interviewees were in their twenties and thirties. Five of the respondents were parents. All were resident in Belfast, except for three; one who had emigrated to England and was visiting home and two who lived outside of Belfast but travelled into the city regularly. Both authors were involved in the interviewing, with the majority of interviews hosted by the second author. Interviews were arranged through several organisations including the Rainbow Project, Northern Ireland Gay Right's Association, Queer Space, Lesbian Line, and Gay and Lesbian Youth Northern Ireland, in addition to personal contacts. To aid analysis all the interview transcripts were coded into NUDIST, a qualitative data-management package, by the first author. The method of analysis adhered to that prescribed in Kitchin and Tate (2000): description, categorisation, and connection.

It should be noted that our analysis centres on our interviewees and therefore does not relate the stories of sexual dissidents such as men-who-have-sex-with-men but

(4) Transgender individuals are those who choose to live as members of the opposite sex to which they were born but have not undergone any gender reassignment surgery. 
do not gay identify, or the many individuals who have left Northern Ireland in order to create lives in more 'tolerant' or cosmopolitan places such as London, Dublin, Manchester, or further afield. In addition, we do not divide the discussion between gay men and lesbians. Although we acknowledge that many studies would indicate significant differences in their sociospatial lives (see edited collections: Bell and Valentine, 1995; Ingram et al, 1997; Valentine, 2000; Whittle, 1994), in our case we found that both groups almost invariably discussed the same issues, employed the same strategies of self-regulation, and largely shared the same social space and organisations. If anything, the internal differences were greater than the differences across the two groups. In the next sections, pseudonyms are used in order to render anonymous our interviewees.

\section{Belfast: a heterosexist city?}

To date, there has been little research concerning sexuality in Northern Ireland, although there is a limited literature on the heterosexist discourses that shape the lives of sexual dissidents (see Conrad, 1998; 2001; McClenaghan, 1995; Mulholland, 1995; Quinn, 2000). These essays tend to focus on the links between sexual identity, sectarianism, and nationalist politics. From their analysis and our own, it is clear that much of the heterosexism in Northern Ireland, although drawing on common heteronormative discourse, is supplemented by religious, postcolonial, and political discourses that create particular sexual productions of space; ones that are often cross-cut by sectarianism (see Kitchin, 2002) This was perhaps most highly visible when the Democratic Unionist Party (DUP) sought to block the decriminalisation of homosexuality through its 'Save Ulster from Sodomy' campaign, which was defeated through the European Court of Human Rights, allowing decriminalisation in 1982, some fifteen years after England and Wales. From then on, the DUP and Ulster Unionist Party have remained opposed to homosexuality. Similarly, although the Nationalist parties have antihomophobic policies, they have generally resisted pursuing sexual rights for fear of alienating more conservative constituency members (Conrad, 1998). In addition, paramilitary organisations on both sides foster what might be termed hyper(hetero)masculinity (Lysaght, 2002) and police their local communities for what it views as antisocial behaviour, which often includes sexual dissidence. Those who have been rumoured, or proven to be gay, or indeed involved in prostitution, have come under pressure to leave, tightly knit, local communities. Consequently, whereas Belfast is not necessarily more heterosexist than cities elsewhere in the United Kingdom, heterosexism, and its discursive and material practices, is relatively unique.

Sexual conservatism and heterosexism, our interviewees claimed, is widely manifested in a number of ways, including weak legislation, unsympathetic and hostile policing, and homophobic intimidation and violence. For example: Northern Ireland is the only place in the United Kingdom where abortion is still illegal; it has a higher age of consent than elsewhere in the country for heterosexual and same-sex intercourse (age 17, as opposed to 16); and, as noted above, it was the last part of the United Kingdom to decriminalise homosexuality. Moreover, although a whole series of antidiscrimination legislation has been introduced in recent years [for example, Race Relations (Northern Ireland) Order, 1997; Fair Employment and Treatment (Northern Ireland) Order, 1998; Disability Discrimination Act (1995); Northern Ireland Act (1998), Equality (Disability, etc) (Northern Ireland) Order, 2000], as yet, sexual orientation is only covered explicitly in the Northern Ireland Act (1998) when an obligation was placed on public authorities to promote equality of opportunity. In addition, the Sex Discrimination (Gender Reassignment) Regulations (Northern Ireland) (1999) provides legal rights for those who have transformed their gender through 
'medical supervision' [clause 2(1)]. The Protection from Harassment Act (1997) has, as yet, not been extended to Northern Ireland; as a consequence, discrimination in relation to sexual orientation is one of the few aspects of identity politics not covered by legal redress (with the exception of public authorities).

Although the apparatus of the state limits sexual citizenship, by far the most prevalent means employed to reproduce heteronormative hegemony in Belfast is intimidation and physical violence. The vast majority of our respondents had experienced various forms of homophobic intimidation and violence at some point when living in Belfast and nearly all feared its occurrence (although a minority accepted it as an inevitable aspect of being gay; usually those who were visibly 'out' and who had experienced it more frequently). The forms of intimidation and violence experienced included name calling, verbal abuse and threats, hate mail, staring, spitting, cold shouldering, school bullying, vandalism of property, forced eviction, and physical attack (also see Comstock, 1991; Herek and Berrill, 1992). That said, it is important to stress that the rates, forms, and effects of homophobia varied markedly across the interviewees. So for example, although a couple of individuals had experienced sustained intimidation and violence over a long period of time, generally it was only experienced sporadically. Incidents of physical attack were rare, although most had witnessed incidents or knew victims. Most prevalent were psychologically based homophobia such as verbal intimidation, cold shouldering, staring, and spitting. A couple of interviewees reported that they could think of no incidents where they had been subjected to explicit homophobic prejudice, although both were 'closeted' and feared such prejudice. Conversely, those who were identifiable as gay through their dress, gait, and so on, reported the highest levels of homophobic harassment. The variation in explicit prejudice is then partially reflected in the extent to which interviewees were out as gay or indeed identifiable as such. Indeed, fear of intimidation and violence meant that 'passing' (posing as 'straight') and the compartmentalisation of visible sexuality was an important self-regulatory strategy used to manage everyday lives, and no doubt contributes to much lower rates of homophobic incidents than if the gay population were more visible (also see Brown, 2000). Rates of intimidation and violence also varied, as a function of location within the city, as Anthony detailed:

"But labelling the city as homophobic, I think it depends. Belfast has many different areas as well. Like, I would feel really safe up in the university area. It depends on your location as well, and where you're coming from. Again, even from the homophobic side of things, there are certain areas where you would feel a lot safer in, and more confident to challenge."

As we document below, forms of homophobic intimidation and violence take place in a multitude of different spatial arenas including the home, workplaces, schools, pubs, clubs, and modes of transport and are perpetrated by a similarly diverse set of actors such as family, friends, work colleagues, bosses, school teachers, bar staff, other customers, and so on. Quite clearly then, these institutional and public expressions of heterosexism, and perhaps more importantly the fear that they induce, have a number of sociospatial consequences to the everyday lives of sexual dissidents living in Belfast. Before we go on to discuss these, it is important to note that, although the discussion so far paints a highly negative picture, a number of institutional changes are occurring.

In recent years, there has been the formation of a number of politically aware organisations, such as Queer Space, Coalition on Sexual Orientation, and The Rainbow Project, which have joined more established groups such as Northern Ireland Gay Rights Association in campaigning for sexual rights, liasing with statutory agencies in adopting new policies, and providing services to sexual dissidents. In addition, a variety of antidiscrimination legislation has been introduced (although as noted above 
this only covers sexual orientation in relation to the public sector), including the establishment of an Equality Commission which campaigns for a more inclusive society; and the Royal Ulster Constabulary has introduced a Force Order (July 2000) addressing homophobic incidents, and appointed a Community Affairs Sergeant responsible for liaison with the gay and lesbian community in each of its thirty-eight divisions - the Sergeant has started to liaise with gay organisations about such issues as cruising. Moreover, there has been a general liberalisation of society. This means that, although our interviewees generally considered Belfast to be a heterosexist society, most felt that institutional and public attitudes and responses towards same-sex relationships are improving (although still had a long way to go before being acceptable). In addition, the gay population is becoming more confident in publicly expressing their sexuality, and sociospatial relations are changing through processes of resistance, such as the annual Pride Festival.

\section{The effects of heterosexism on everyday life}

In general terms, in order to manage heterosexism and to avoid unwanted homophobic intimidation and violence, our interviewees employed a range of spatial strategies. Predominant amongst these were 'compartmentalisation', 'self-policing', and passing. Compartmentalisation consisted of individuals dividing up aspects of their lives into places or situations in which they were willing to be out, and those where they sought to keep their sexuality hidden. As Paul explained:

"There are different levels of being out. Somebody who was closeted would be perhaps somebody who doesn't want to tell other people for fear of rejection and the isolation. And you have people who would be out-out, and everybody knows, but they are comfortable with that.... If you lead an out-out lifestyle in Belfast you really have to-curtail is the wrong word-but you have to be conscious of the choice that you have made in all other areas of your life. So... perhaps there's certain bars you won't go to, there are certain places you won't socialise in because it's prioritising what's for you and being comfortable and not having that fear of having to tell somebody that you are gay. So that's the choice some people make and some people go in between. So a lot of people see 'out' as black and white, but in reality it's shades of grey."

The second, related, strategy of self-policing is also mentioned within Paul's description. This is the careful management of where one visits (whether identifiably out or closeted), and the self-surveillance of clothes, behaviour, mannerisms, and so on that might lead to the identification of sexuality. As Jason explained:

"I think everybody learns to have coping mechanisms. The big, major thing is that you are very, very careful about displaying affection, or about being yourself in public. Like, you rarely see in Belfast two men or two women holding hands in the street."

In addition to self-policing the social information communicated to strangers, whether in the form of wearing supposed 'gay clothes', 'camping it up', or toning it down in public arenas, some respondents also spoke of policing their behaviour in ways which were clearly directed toward those more intimately linked to their daily lives, whether siblings, nieces, mothers, school friends, work colleagues, or neighbours. They spoke of overcompensating behaviour, whereby they ensured that they were a better aunt, a more dependable daughter or son, a quiet neighbour, a hard working colleague, and a loyal friend. Passing was a form of self-policing and consisted of acting as if straight and, if necessary, reproducing heterosexist behaviour to avoid raising suspicion.

The extent to which these strategies (and others) were used, usually related to spatial and social context, and the individual's confidence and self-esteem: a few would 
use them sparingly, others would use them almost continuously, with the majority somewhere in-between. Not unsurprisingly then, their use led to highly varied geographies across the interviewees, with a few respondents out in all spatial arenas, others selectively out depending on circumstances, and a minority closeted in all but a few situations such as visiting a gay bar (where they would be fearful of being identified and 'outed'). In the next sections we detail the sociospatial variations in our respondents' experiences of particular spatial arenas and the tactics they used to manage heterosexism. Whereas there is little explicit discussion of sectarianism, it should be noted that sexual production of space is sectarianised in at least three ways. First, as noted, the bounds of heteronormativity in Northern Ireland are partially defined by religious, postcolonial, and political discourses. Second, there is a sectarian effect on general patterns of residence, employment, and travel that produces a highly segregated and territorialised landscape (which affects sexual dissidents as much as any other social group) (see Boal, 1978; Doherty and Poole, 1995). Third, though most of our respondents suggested a limited effect, sectarianism operates within the gay community (just because one is gay does not mean that one is not a Nationalist/ Republican/Catholic or Unionist/Loyalist/Protestant). In relation to the first point, the bounds of heteronormativity in Northern Ireland, there was interestingly a general perception amongst our respondents that it is easier to be Catholic and gay, than Protestant and gay (though nobody could provide any concrete evidence that this was the case). In regards to the latter two points, as with heterosexual partnerships, cross-cultural relationships can be stifled or never realised because of fears of sectarian (rather than homophobic) violence when visiting a partner living in territory controlled by the 'opposing side'. Clearly, how much one fears such repercussions delimits sociospatial behaviour, as Matthew and Robert explained:

Matthew: "Well [where one lives] can put people off. Well, I'm like that too. There are areas that I won't go into. And if I met someone and they lived in certain areas, I would say 'No, I'm sorry'. I would explain to them why. But at the end of the day, you do have reservations about it. That is the nature of Northern Ireland, it's the way things are here."

Robert: "Oh yea, if someone from south Belfast met someone from Twinbrook and said, 'Come back to my place', they wouldn't feel safe there. There was a fellow, a Protestant, from East Belfast living with his father, and his boyfriend lives in West Belfast, and he said he was terrified coming up to West Belfast. He was very frightened, and his boyfriend is afraid to go the other way."

\section{Home}

Clearly, one of the most important spaces for people is that of the home, the site of supposed security, freedom, and control. To date, little geographical work has focused on the spatiality of home in the context of sexuality, with the exception of Johnston and Valentine's (1995) study. They detail, in relation to lesbians, that sexual identity is often hidden in the parental or family home where surveillance by parents can make life difficult. This is particularly the case for those lesbians who have not yet 'come out'. Those who have come out can still come under vigilant surveillance that forces them to modify their behaviour which, although deemed acceptable to heterosexual couples such as kissing or holding hands, is deemed out of place in the heteronormative space of the parental home. As such, meanings attached to, and experiences of, this home can be highly contested. This can also be true of the lesbian home itself-when family members may visit. For example, Johnston and Valentine (1995, page 106) report that some lesbians may "de-dyke the house completely, others make more subtle changes depending on the level of discomfort likely to be expressed by visitors or experienced 
by the occupants". Lesbian households also have to negotiate neighbours and the potential of their home being placed under neighbourhood surveillance and also being affected by homophobic intimidation and attack. Johnston and Valentine's observations were evident in our own analysis, both with lesbians and with gay men carefully selfregulating their behaviour in relation to the family home and to their own residence. As we detail, however, this pattern was far from universal.

\section{Family home}

As we discuss below, social space tended to be a 'grey' area in which respondents were selectively 'out' according to place, time, and context, whereas the family home tended to be a 'black or white' place; respondents were either out or closeted. If the latter, then this tended to be well protected, so that their sexuality was hidden from all family members for fear of 'loose talk'. As Steve explained:

"I am continuously lying to members of my family. I continuously lie to my sister. I went out last night to the Crow's Nest with this bloke I've started seeing, and at times I went out with different friends, and I don't like doing that. I don't like doing that to her, it doesn't respect her because we get along quite well. It doesn't respect him very much either."

If family members were told selectively about an interviewee's sexuality it tended to be siblings rather than parents, and they were often sworn to secrecy. The reasoning behind this was twofold, first, to protect the interviewee's relationship with family members and second, to protect the family from homophobic reactions by neighbours and family friends. In relation to the first point, the fear was of being ostracised from the family, a reality experienced by a couple of interviewees who had come out at home or more commonly had been 'outed' by somebody else, as Jonathon illustrated:

"After the teacher told that to my Mum and Dad, I came home and they beat the shit out of me, you know. I can remember my Da screaming 'Nothing disgusts me more than queers.",

This experience is contrasted with the views of Tim, who suggested that coming out to family members is becoming more common and is being received in less dramatic ways:

"But I don't even hear as much now about people getting thrown out of home and things like that. I remember when ... you would have heard about people who went to their parents, and they came home the next day to find the bag sitting on the doorstep, locks were changed.... Whereas now you just don't hear about that kind of response as much. There might be an uncomfortable period at home or whatever, but people get used to the idea. But there isn't that out-and-out rejection of people as much. I'm sure it still happens for some people, but I don't think it happens as much now."

Where family members did know about an interviewee's sexuality, the second factor often came into play, so that it was kept within the family or close friends for fear of the impacts on other family members. For example, Andy stated:

"At work, I'm gradually getting the courage to come out... but down at home it's completely different, close family, close friends, and that's it. You just don't talk about it."

Similarly, Anthony's brother wanted him to keep his sexuality a secret because he was worried about the security of his own job and his role within a youth organisation. The fears that other family members could become victims of abuse themselves or ostracised from the local community is real, although variable, as illustrated by Sean:

"My parents used to get milk bottles thrown at their windows and 'faggot' scraped on the car." 
In particular, the position of school-age children was a concern, with the fear that if it was known that an older brother or sister, or an aunt or uncle, was gay that the child would be bullied by other children. In general, interviewees (both those out and those closeted) took it upon themselves to self-police within the family home and local community, as James explained:

"I came out... when I was twenty one, my father sort of sat and stared and my mother of course did the crying thing, and then she went and she spoke to one of the charities - I don't like saying this because it sounds bad-she got over it, she got over herself. My last boyfriend, she told me loved him as much as she loved me. As long as we weren't all over each other on the settee, they were fine about it. But I knew I couldn't kiss him in front of my parents. I couldn't hold his hand either."

Although, in one case, Anne described how one of her gay friends who did not carefully self-police his behaviour was policed by his family, so for example they encouraged him to tone down his dress near to the family home:

"And he had to wear this shirt out. And she said 'Would you please wear it when you're coming back again. I don't want the neighbours looking out and seeing you wearing that top, or knowing where you're going.",

\section{Interviewee's home}

Whereas the family home was a place owned by parents and shared with siblings the home of the interviewee offered significantly more freedom and control for self-expression for the majority of respondents. It was a space in which they could 'be themselves' without need for self-policing of appearance or behaviour. However, where children were involved and the parent was closeted from the child(ren) then the homespace became more problematical, and in the five cases of parents we interviewed, sexual or romantic relationships were usually conducted away from the home and potential discovery by the child. This was to protect the parent and child from having to confront the parent's sexuality, and also to protect the child from being bullied at school.

One of the most significant freedoms associated with the interviewee's home was that they could choose where in the city to live, a choice that was often highly influenced by their sexuality. So, for example, many respondents tended to try and avoid spaces that were seen as working class and highly sectarianised because of the scrutiny residents in these areas are under. For example, Simon and Anne explained:

Simon: "I think there is a big distinction between, for example, working-class areas and middle-class areas. I think it is easier for gay people to live in middleclass areas than in working class. I don't know if that is down to educational influences or whether the middle-class areas would be more at ease with a greater degree of anonymity, because they tend not to be dominated by terraced houses. [They're] a bit more semi and semidetached. So the fact that the houses are physically not together, there is a greater degree of anonymity.... I think in some of the neighbourhoods or areas that are very, very obviously of a certain particular political persuasion... they have an atmosphere of a small community, which is very different. The social dynamics are somewhat different. In a small community everybody likes to know everybody else."

Anne:“... living in housing estates there is that thing, that anybody who doesn't fit into either Protestant or Catholic is different, so therefore they are a target for being a victim or getting a hiding or whatever else." 
As a result of the perceived difficulties of living in sectarian and working-class neighbourhoods, many of our respondents had chosen to live in the south of the city in the sector between the Ormeau Road and Lisburn Road, in areas such as Ballynafeigh, Stranmillis, the Holylands, and around Queen's University. With the exception of the inner-city part of this sector (such as the working-class, religiously segregated areas of Sandy Row, Lower Ormeau, Donegal Pass, and the Markets) these areas are generally more mixed in population type, both in sectarian and in class terms, have large proportions of rented and shared accommodation, and the population is quite transient. The area generally has a more cosmopolitan feel, with large numbers of cafes, restaurants, and pubs catering to mixed populations on each of the principal roads leading south [accounts of other cities similarly note that such areas have been popular residential areas when the gay population has still been largely hidden (see Beemyn, 1997; Chauncey, 1995)]. This concentration seems to be recognised to a degree by housing agencies such as the Housing Executive and Belfast Improved Housing, who appear to place gay people, who have been intimidated out of accommodation in other parts of the city, into housing in this sector. This is not to say that other areas were largely devoid of sexual dissidents: our interviewees were drawn from all parts of the city. Indeed, with house prices rising, in the years after the Northern Ireland ceasefires, many people were forced to contemplate their first house purchase outside the hugely inflated price zone of the university area of south Belfast. Some people moved to adjacent areas in the southeast of the city, entering districts which traditionally held a working-class Protestant population. With increasing suburbanisation of the Protestant population in Belfast, houses were vacant and affordable in these traditional communities. Despite the existence of paramilitary elements operating locally, word spread within gay and lesbian networks of safe streets, safe areas, or gay-friendly landlords and the district has seen a steady flow of new arrivals.

Despite a seeming concentration of the gay population in the south and southeast of the city, it is a concentration that remains largely invisible - as with elsewhere in Belfast. The reason for this invisibility is that the interviewees' homes were often carefully self-policed, particularly in relation to neighbours. Respondents often went to great lengths to protect their sexual identity from other residents for fear of inducing homophobic reaction [for similar accounts of such self-policing in other cities see, Beemyn (1997); Bell and Valentine (1995)]. For example, in the next passage Simon explained how he carefully manages his relationship with his neighbours:

"At the moment I am living just outside Belfast, and it's very, what you would call a middle-class area. It's all semidetached housing. So I can put a certain distance between myself and the neighbours. And I do. I don't invite them to get to know me too well. And that's the way. Well, first of all they get the message not to pry.... Part of it is being polite and saying 'hello', and not offering too much information. And if they do ask questions, then you give them either vague answers or you just give them an answer which doesn't really answer. They sort of take a polite hint that they are asking too much.... I would be hesitant about bringing a large group of people to the house, especially if alcohol is involved, because then people become less aware of how extrovert they can become, and they might say something. So even though I own my own house, and the property is mine, I should be able to do what I want, and in many ways I can't."

And Carl explained how sexual dissidents protect their own and other individual's property: 
"You don't want to go out the door if there's a lot of people around because you don't want to draw attention to the person because they have to live in that area. And you don't want attention drawn to yourself. So usually gay people protect themselves, from the homophobic point of view, by living as low key as they possibly can.... I think gay people in Belfast have to be extremely quiet and mannerly sometimes around their neighbours, because they simply don't want any hassle and they just want to be accepted as people who are just getting on with their lives. And I think there's enormous pressure on them to be like that."

Respondents also spoke of strategies of not wearing overly gay clothes when entering or leaving their home, choosing instead to change on arrival at their ultimate destination; of not ordering local taxi companies to take them or friends to gay venues as their identity, sexuality, and home address could become local knowledge. Although free to hold hands, kiss, and cuddle in the privacy of their own homes, some respondents spoke of their awareness of the lack of soundproofing between terraced houses, which made them sensitive to the extra male or female voice in the bedroom at night or in the morning. One female respondent noted her discomfort when being visited by her partner, who would park her car in the driveway overnight. The woman spoke of feeling that the presence of the vehicle would lead neighbours to gossip. She welcomed regular visits from a male friend, sensing that they would act to offset the neighbours' speculation.

Fears of a negative reaction from neighbours or others in the locality were not entirely unjustified, as in a few cases respondents had been forced to move because of homophobic intimidation or perceived negative attention; or knew of cases of other sexual dissidents for whom this was the case. For example, in the cases below, Mark details his own experiences of being forced to leave his home, and Anne relates a story of her friends who were similarly told to leave an area. These two cases clearly crosscut with sectarianism and community policing by paramilitary groups:

Mark: "They broke into my flat, and round the walls it said 'Queer Orange... Bastard'. I was called everything. This is what they were writing on the walls in my flat ... . And that's when I said 'That's it. I'm not putting up with it anymore. I'm moving'. I rang the Housing Executive and told them, and they said 'Well, you are registering yourself homeless'. And I said 'Well, I'd rather be homeless than living in an environment where I have to put up with this'. I had got to the stage where I had to stay in twenty-four hours a day."

Anne: "And I was talking to one of these girls who lives two or three streets down from us, and she was saying they got a knock on the door one night, and they were told they had to get out.... They were told to get out because they were lesbians. ... They were given that reason - that they were gay. They didn't want people there with antisocial behaviour."

That said, some respondents did not seek to hide their sexuality from their neighbours. These were usually people who had lived in the area a long time so that they were well known to local residents before it was known that they were gay. In these cases it seemed that long-term friendships or acquaintance protected sexual dissidents from the worst excesses of homophobic violence, as long as they did not flaunt their sexuality outside of their home. Moreover, as Carl details, in some cases where sexual dissidence had been recognised by neighbours, nothing untoward had happened because they were not perceived a threat:

"I've... heard different people in Belfast say that neighbours have discovered that they are gay and they have no problem with that because they are quiet and very mannerly." 
Again, it is clear that the sociospatial processes shaping the residential lives of sexual dissidence vary across place and context. For people living in the city, their own personal circumstances and the neighbours encountered, leads to different experiences. Whereas the testimonies of some respondents illustrate that they do fear homophobic reactions from neighbours if sexual identity is discovered, others suggest that as long as behaviour is self-regulated, in a manner satisfactory to other residents, then indifference is shown. Indeed, several respondents noted that they felt the need to overcompensate for being gay: by being a better neighbour, a quieter resident, and ensuring that they did not provide any reason for the neighbours to dislike them. As such, they saw homophobia as a secondary reaction to other triggers, which they could attempt to control. There is no obvious pattern in these reactions, although it is clearly classed to an extent and tolerance seems to be more prevalent in the south of the city where the population is more mixed and transient, and where neighbours might be used to a variety of social behaviours (for example, student housing).

\section{Workplace}

Tim: "Employers will sometimes use the one that says 'We believe you are gay and we can't guarantee your safety in work, therefore we will sack you. This is a homophobic environment. It's not safe for us to employ gay people in a homophobic environment. And we're not prepared to take responsibility, so therefore we're letting you go.",

As with the home, institutionalised spaces such as school and the workplace are unavoidable locations in which individuals spend a great deal of time. Being labelled and treated differently in these environments has serious long-term consequences, for example in the workplace, in relation to job satisfaction and job security [for an example in relation to gender see McDowell (1997)]. This often leads to sexual dissidents guarding their sexuality in these settings for fear of being ostracised by colleagues. The situation is changing to a certain extent, especially in the public sector where the Northern Ireland Act (1998) now provides legal protection from discrimination, with the result that some of our respondents did not feel that they had to hide their sexuality but neither did they feel free to flaunt it. This is not to say that these interviewees do not experience homophobia, but that they are more likely to confront and challenge it.

Most of our interviewees remained closeted within the workplace, although this certainly was not universal, with the experiences of those out or outed varying with work environment. Of those out, intentionally or not, homophobia was often a feature of the workplace and undoubtedly did negatively affect work experiences. For example, some interviewees reported being cold shouldered and ostracised from decisionmaking and social aspects of work, as Robert and Sean explained:

Robert: "Your work mates-you can't choose them. I worked with homophobic people.... You can work all right, but you find it sort of stressful and you can't be yourself. That was very much part of the civil service at one time, that I worked with some homophobic people and they would talk about you behind your back and everything."

Sean: "I worked in [shop] and somebody asked 'Are you gay?' and I went 'Yea', and that was it, they never spoke to me. That was it. Not one word was spoken to me. No one spoke to me.... People won't drink from the same cup as me in work in the job I have now. I've noticed. Because we always share cups.... But everybody else shares the same cups and the same forks and same spoon. I know. I see it. I've offered people a cigarette, and they say 'No'." 
Below, Simon explains that gossip is a central part of shop floor and office life, and that people's sexuality often forms part of that gossip. Because he did not discuss his social life and did not join in with certain discussions he was quickly labelled as gay, although he did not come out:

"And the shop floor environment, you've got hundreds of people in a very closeted environment. They are trussed together for eight hours a day or whatever their shift is, and of course they're going to gossip. And they're going to wonder. They're going to ask questions and all the rest of it. And basically, they just suss you out. They like to know where they stand with you. The fact that I never discussed ever having a girlfriend, and the fact that I wasn't too keen on discussing where I socialised outside of work, and the fact that I found it a bit difficult to relate to straight men because they were always talking about women and football and lager and things like that. The perceptive people at work sussed it out. And basically they just said to me 'We know'. And I said 'Know what?' And they just said 'We know what way things are with you'. It spread like wildfire."

Instead of denying the accusation, Simon decided to carry on as before and see the situation out, using his position within the company to try and maintain respect:

"But I thought 'To hell with it'. I got to the stage where my own sense of self-esteem about being gay was sufficient to carry me through that. A few years ago it wouldn't have been like that.... I was very lucky in the fact that I joined the company in a somewhat senior position. And I would have a lot of influence over how well other people would have done. So they would pay me a certain amount of respect."

Simon noted that the degree of acceptance given to his sexuality was directly related to his relative power within the organisation. As the manager in charge of the shop floor, negative homophobic reactions from those he supervised could have proven more detrimental to their working day than it would have to his. Indeed, unlike Robert and Sean, colleagues appeared to quickly 'forget' that he was gay and he could get on with his job:

"The only change I noticed was, not so much in managerial attitudes, it was more the shop floor. I found that a lot of people relaxed and eased up once they found out and knew where they stood. And the day after they were talking about somebody else anyway. Like once they find out, that's it, and they move on to the next one."

As such, Simon discovered that his work colleagues would tolerate his sexuality as long as he got on with his job and acted in a professional manner. However, despite being accepted on the shop floor and by those in management positions, Simon did eventually leave his job because of the homophobia displayed by the personnel manager who ultimately decided how his career would progress in the company:

"One of the reasons why I left that company was that the person who was in charge of personnel.... He... pronounced me one day as an abomination. And I thought my chances of career progression are not going to be good with this guy in charge, because he basically single-handedly decided who got promoted."

Here it was individual, rather than institutionalised, homophobia that affected the work environment; Simon felt powerless to challenge the manager's position, especially given that there is no antidiscrimination legislation covering private sector employees. In his new job Simon is not yet out because he knows that his new boss is homophobic and he again feels powerless to challenge those attitudes.

Other interviewees also revealed that they were out at work, but so far had not suffered unduly from homophobic harassment. These were generally people, such as Pamela and Anthony, who worked in professional positions in the public sector where legislation provided protection from discrimination: 
Pamela: "Where I work is fine.... as far as the colleagues go, they are OK."

Anthony: "Some of my colleagues do know, because I chose to tell them. And there is one or two gay people, and our work environment is quite good with their visible policies insofar as it is up there with the rest, with race and sex and stuff. So you've got official backing that you can't be harassed or discriminated against because of your sexuality. So it makes it a lot easier. Previous jobs, there was no way, not a hope in hell."

Several of our respondents noted that they were particularly attracted to public service employment because of the legislative safeguards protecting them from discrimination because of sexual orientation. They viewed the security of such an arrangement as a significant incentive when compared to similar or better paid opportunities in the private, unregulated, sector.

So again, experiences of work space are differentiated, varying across employment sector, place of work, and work colleagues, although on the whole individuals tend to self-regulate their behaviour in order to protect their sexual identity; and it was only when such self-policing failed and they were outed by colleagues that they tried to confront any homophobic reaction or in the worst cases moved to a new job.

\section{Social space}

Unlike home or work, social space was the arena in which our interviewees were much more selective when revealing their sexual identities, and consequently their actions and dress: dependent upon place (for example, gay bar, straight pub) and context (for example, who they were with). As such, interviewees used a range of different strategies for meeting new people and maintaining social networks, which normally also served to protect their sexual identity if so desired. These included attending gay bars, developing nonscene networks, using contact magazines or the Internet, and cruising.

Unlike many other cities which have come under the academic gaze, such as San Francisco (Stryker and van Buskirk, 1996), New Orleans (Knopp, 1990), Vancouver (Brown, 1997), Manchester (Moran et al, 2001; Quilley, 1997; Whittle, 1994), London (Mort, 1996), Toronto (Bouthillette, 1994), and New York (Chauncey, 1995; Kaiser, 1997; Rothenburg, 1995), Belfast is a city with very little visible gay space, either residential (as noted above) or commercial. At present, commercial space consists of two openly gay venues (The Kremlin and the newly reopened Crow's Nest, now renamed The Customs House) and the offices of gay organisations such as Queer Space, The Rainbow Project, and Cara Friend. The Parliament (a previous gay venue) now cites itself as 'gay friendly', although our interviews reveal that it is progressively becoming more straight (see the quote by Mark below). A concern expressed by some of those using the area occupied by the gay bars is the influx of straight people into the newly named 'Cathedral Quarter' both because it erodes 'gay space' and opens up the space to a heterosexist gaze that threatens its users with exposure and outing [for a similar process in Manchester, UK, see Moran et al (2001)], as Mark and Simon noted:

Mark: "There is a gay community, but, I mean, it's sort of inundated by the straight community as well. You have a mixture which I think you are always going to have, because you can't discriminate to the point where you are not going to have anybody straight in the bar. So you are going to have some straight presence there. Sometimes it's hard to tell whether the bar [The Parliament] is gay or straight or whatever. I would prefer a place that is exclusively gay because then you can be yourself and not worry about what anyone thinks. Whereas if you have a place that's inundated with loads of straight clientele, they are not all going to be gay friendly. It's the ones that aren't that you have to put up with, which, to me, you shouldn't have to put up with." 
Simon: "There was this morbid fascination by a lot of straight people.... And then all of a sudden it's all over work that 'Oh, did you know so and so is gay? I saw him in the Parliament last night'. It's OK for a straight person to go to the Parliament, but they have nothing to lose by it, whereas somebody who wants to keep a very discrete lifestyle and they want to delineate that social aspect from their professional life. And all of a sudden that segregation has been broken down. I choose not to go to the Parliament.... And that is based on the fact that so many straight people go [there]. And because I'm not really out at work, there would be certain fearfulness of being outed, being recognised."

Rather than expanding then, the 'gay scene' is seen by some as under threat, victim to gentrification as the city centre, a supposedly 'neutral' space, is redeveloped in the wake of the Northern Ireland Peace Agreement. A limited number of other bars hold gay nights, but are considered to be strictly heterosexual for the rest of the week. There is a once monthly 'women-only night' at one bar in the city centre. Gay space outside of Belfast is severely limited, with one gay bar in Derry, the North's second city. Although Belfast is a small city compared with London, New York, and San Francisco, this commercial scene is still extremely small when one considers that Belfast is the principal city in Northern Ireland with a population of 476000 residing in the Belfast Urban Area according to the 1991 Northern Ireland census.

This clearly has impacts on the opportunities for sexual dissidents living in the city to socialise in an openly gay and nonthreatening environment, and to meet potential partners, as Robert detailed in a comparison with London:

"There are so many things to go to [in London], I mean if you are into particular bars, or music, you know. There's a gay Asian bar. They have all different things, different strokes for different folks. Whereas in Belfast, all these gay people-it's like there's one straight bar in Belfast and you can imagine everyone going to it, you know, you want to find your partner in one straight bar, you know, it's like that. And you have nothing in common apart from the fact that they are gay. In London you have all the different scenes and interest groups and all that sort of stuff, and there's just a lot more gay people around."

As such, the gay scene was viewed by a number of our respondents as limited not only by the numbers of venues but also in terms of the type of venue. Unlike other cities, Belfast does not have a sophisticated set of venues, catering for different clientele. Moreover, although much valued, the scene operating in The Kremlin and at other 'gay only' events is acknowledged to be shallow, hedonistic, and primarily about meeting sexual partners rather than developing friendships, as Paul and Robert explained:

Paul: "My own personal perspective, to a degree, is that the gay scene encourages shallowness among people and falseness. There's this sort of false sense of community - 'we're all here in this gay bar, we're all fabulous and we're all happy'. Do you know what I mean? And that's not the reality. So that doesn't particularly appeal to me. So I just tend to head out elsewhere... The gay community for people is going out, meeting somebody, perhaps having sex, going out, getting drunk, taking drugs and then back to normal during the week."

Robert: "Another big problem that gay people have is when they go to night clubs it is hard to make friends because if you talk to someone it's assumed you are trying it on with them. And how do you get to the stage where you can talk to them and don't want to get off with them? I find, in my case, that you only make friends, gay friends, outside the gay scene, or you are introduced to someone by someone who has a gay friend.... And that's a lot easier than actually going to the gay scene, which is very heavy, very sexual.... It takes courage to 
chat someone up and find things in common with them. Some people prefer to get off with them rather than have a conversation. They have the conversation the next day. So in that sense it's pretty antisocial."

The seeming shallowness of the scene thus excludes many gay people, who feel out of place in a highly charged sexual environment that seems to privilege the 'body beautiful', as Darren described:

"No, it's not for me anyway, and I've never really felt comfortable about it. I think it's very two dimensional. You're just a body.... It's like a glorified beauty contest.

It's quite destructive."

In answer to this need, one social group has been established in an effort to allow people to come together and build friendships through a variety of social events. Men of the North aims to provide social opportunities for those who do not see themselves as, or indeed have graduated from being, 'scene queens' and 'Twiggys' of the club circuit.

In addition to the limitations of the scene with its associated fear of being spotted by straight colleagues and friends, use of the bars is regulated by the journey to and from the venues. Because the bars are in a part of the city centre where few venues would have been open in the evening; until recently (and still to an extent) it was assumed that the people walking into or out of the area would have been gay. Travelling to and from these bars posed a safety issue. Generally, people would not travel alone and would use a taxi to get to the city centre. Instead of taking the taxi to the bars however, some respondents would seek to be dropped somewhere nearby, from where they could easily be perceived to be travelling elsewhere. From their drop-off point they would carefully self-police their route to the bars, monitoring other pedestrians and the movement of cars, to ensure that they would not be recognised or attacked, as Kim explained:

"I would always be over aware of safety. And in actual fact so much so that if any of my friends would ask me to go down to these bars to meet them for whatever reason, I would get a taxi into town, but not get the driver to leave me off outside the front door. I just wouldn't do it. There's no use provoking people.... 'Drop me at the bottom of Castle Street', and then I'd simply walk down. I would not identify the actual places that are gay, no way."

Similarly, when leaving the bars respondents would not use the closest taxi office, but instead would walk to a gay-friendly company nearby. This strategy of using a 'safe' taxi company, or getting dropped off in a safe space, clearly aimed to protect the individual's sexual identity from other people in the area and the taxi driver (who necessarily knew where they lived); it was common knowledge that many (but certainly not all) taxi drivers were homophobic and that taxi usage posed certain potential risks, as the comments below from Anne and Sean illustrated:

Anne: "She started slabbering. She said, 'Where did you come out of? I bet you came out of that fuckin' Kremlin, didn't you?' And I was like, 'I don't think it's any of your business where I came out of.' She had about twelve mates with her and I'm there on my own, not knowing a gay person in sight. And one of the guys working in the rank said to me, 'Where are you going to, love?' And I told him. And he said 'Right, you can get the next car.' And I was like, 'Why? All these other people waiting here'. And he said, 'I want no trouble in here.' And I said, 'I don't either, but I'm happy enough to take a car.' And he said, 'Maybe it would be as well not to come in here at this time of the night when you know all these people are going to be in here." 
Sean: “'Are you'se fuckin' faggots?', he said to the ones in the back. And nobody answered. And I was like, 'I am. What's wrong?' 'Get out of my taxi. Get out of my taxi'. And I said 'No, I paid for you to bring us to the Kremlin'. 'You'se are fuckin' gaylords. You'se all ought to be shot'. And he was driving and I was thinking 'Oh my God, don't look frightened'. And he was mumbling to himself 'It's fuckin' disgusting'. Really freaking out. 'You'se are disgusting. You'se queers, you'se sicken me. This bar shouldn't exist."

Sean also gave another example of where he had been chased by a taxi driver wielding a baseball bat and had been set upon by a number of drivers outside a taxi office for admitting he was gay.

As a consequence of the risks of being outed and the perceived shallowness of the gay scene, many of our interviewees only attended the gay venues sporadically, usually for a particular party or to meet a new partner, although many acknowledged that some (usually young) scene queens (such as Sean) frequented The Kremlin on a much more regular basis. Instead, many of our respondents either attended meetings organised by groups such as QueerSpace, attended specific events such as women-only nights held every month, or formed their own private social network, away from the gay bars. The first two of these consisted of relatively small numbers of people, generally those committed to some notion of a 'gay community', whereas the private network appeared most popular with our respondents. These networks were often perceived as 'couples circuits', away from the sexual predatory bar scene, so as Kim detailed "You met someone and you kind of came off the scene". As Matthew detailed further:

"I've been with my partner for... [many] years now and in a way we've developed our own identity separate from the gay scene. The gay scene is a good place for people to meet each other. But there is an ethos within it that seems to suggest that there seems to be very little connection on a long-term basis. It's good if you want to go out and get a shag one night or maybe short term. I think it's for people who want to meet each other. It's fine and it's a good way for people to affirm their identity and to be with other people who are gay. But it's really just the tip of the iceberg in terms of gay people out there in the world. There's a lot of gay people out there in the world who are in relationships who don't bother with the gay scene, they just lead their own lives separate from it."

Tony elaborated further:

"Most of the guys I've known living there are probably thirty plus now, they're established in their work. It's funny, the majority of them don't associate with the gay scene at all.... They talk about the 'cocktail set'. And that's what they probably are. They're all established in their professions or whatever and earning a reasonable income. Maybe they've done the bar scene, but they don't want that. Some of them just don't want it because they're not looking for that any more. Or some of them are in a relationship and don't want it."

As well as meeting in each other's homes, these private networks also used straight bars, particularly those which had a diverse set of clientele that would protect anonymity, as Simon described:

"A lot of it has to do with choosing various social outlets. You can choose to go to somewhere like [name of bar] and in a way, because you're so exposed to different groups of people there, it is actually a way of preserving your anonymity, because you're not really revealing too much by going there. You're just in the hodgepodge with everybody else. You're not really standing out."

In addition, male interviewees talked about other ways in which to meet other gay people. These included telephone chatlines, chatrooms on the Internet, and cruising. 
These were perceived as being risky as they exposed participants to potential violence, entrapment, and sexual health risks. In fact, most of those we interviewed were negatively predisposed to cruising, with only one person mentioning that he did cruise. Several did report, however, that cruising is quite widespread in several locations in the city, but in their opinion it was mainly undertaken by married men and those too afraid to go to the clubs or those who were unable or unwilling to develop other social networks.

\section{Conclusion}

In this paper we have sought to address Binnie and Valentine's (1999) call to provide a nuanced account of the geographies experienced by sexual dissidents in Belfast, highlighting the ways in which heterosexism is unevenly and unequally expressed. As our analysis highlights, although Belfast can be conceived as a heterosexist and homophobic city with very little visible gay space, when compared with other cities in the United Kingdom and elsewhere, there is a marked variation in how heterosexism impacts on the lives of sexual dissidents. As such, it needs to be recognised that the heterosexist, discursive, and material practices brought to bear on sexual dissidents are spatially, temporally, and contextually differentiated. These practices are complemented by sociospatial processes of self-regulation such as compartmentalisation and selfpolicing of appearance and actions, but are also resisted, subverted, parodied, and challenged. The complex interlocking of regulation, self-regulation, and resistance means that everyday life practices and the spaces in which they occur-such as home, work, and leisure venues-are experienced differently across individuals. Moreover, experiences of intimidation and violence are also significantly differentiated across individuals and also across place, so that some areas are viewed as much safer than others (for example, middle-class, less sectarianised areas, and areas with transient populations such as near to Queen's University), though this also depended on the time of day (for example, some places viewed as safe during the day, were perceived to be more dangerous at night, such as around the bars) and the context (whether alone or in a group).

Our contention is that queer theory provides a useful route into addressing Binnie and Valentine's call (1999), as it allows us to account for the differences and similarities in the everyday lives of sexual dissidents living in the same city. Queer theory recognises the multiplicity and fluidity of sexuality; the difficulties of drawing boundaries around sexual identities that are always in a process of becoming - of being acted out as embodied performances in space. It thus acknowledges that each individual's sexuality is highly contextualised, developing over space and time. Moreover, queer theory recognises that the sexual production of space is in a constant state of becoming: shaped by a range of discursive and material practices of domination and resistance, so that the meaning and experience of space are only ever temporarily fixed. As such, it accepts that the sexing of space is continuously shifting across individuals living in the same places; that heterosexism is spatially, temporally, and contextually contingent.

Understanding the spatial narratives of sexual dissident's lives must consist of the twin practices of deconstructing the ongoing performance of sexual identity and the sexual production of space. Here, we would contend that there is a need to build on work looking at nonmetropolitan sexualities (for example, Phillips et al, 2000; Valentine, 1993) in order to widen the academic gaze and investigate cities where little visible gay space is apparent (rather than focus on large cities where there is visible commercial or residential gay spaces), and where the sexual production of space is crosscut by factors such as religion, nationalism and race-leading to particular forms of territoriality - in order to uncover the sociosexual networks that exist and 
deconstruct the complex sociospatial processes of regulation, self-regulation, and resistance that operate in a variety of different places. This type of analysis will thus give us a much better understanding of the sexual production of space, across a range of places and individuals, allowing us to chart in detail its uneven and unequal nature.

Acknowledgements. We would like to thank the individuals who allowed us to interview them for generously giving us their time and sharing their experiences and thoughts. This paper was first presented as 'Belfast: gay heaven or gay hell?' at Belfast Pride, 3 August 2001. We thank the members of the audience for their thoughtful discussion of the work.

\section{References}

Adler S, Brenner J, 1992, "Gender and space: lesbians and gay men in the city" International Journal of Urban and Regional Research 16 24-34

Bailey R W, 1999 Gay Politics, Urban Politics: Identity and Economics in the Urban Setting (Columbia University Press, New York)

Beemyn B (Ed.), 1997 Creating a Place for Ourselves: Lesbian, Gay and Bisexual Community Histories (Routledge, London)

Bell D, Binnie J, 2000 The Sexual Citizen (Polity Press, Cambridge)

Bell D, Valentine G (Eds), 1995 Mapping Desire: Geographies of Sexuality (Routledge, London) Betsky A, 1997 Queer Space: Architecture and Same-sex Desire (William Morrow, New York) Binnie J, 1995, "Trading places: consumption, sexuality and the production of queer space", in Mapping Desire Eds D Bell, G Valentine (Routledge, London) pp 182 - 199

Binnie J, Valentine G, 1999, "Geographies of sexuality - a review of progress" Progress in Human Geography $23175-187$

Boal F, 1978, "Territoriality on the Shankill-Falls divide, Belfast: the perspective from 1976", in An Invitation to Geography Eds D Lanegrin, R Palm (McGraw-Hill, New York) pp 58-77

Bouthillette A-M, 1994, "Gentrification by gay male communities: a case study of Toronto's Cabbagetown", in The Margins of the City: Gay Men's Urban Lives Ed. S Whittle (Arena, Aldershot, Hants) pp $65-84$

Brickell C, 2000, "Heroes and invaders: gay and lesbian pride parades and the public/private distinction in New Zealand media accounts" Gender, Place and Culture 7163 - 178

Brown M P, 1997 Re-placing Citizenship (Guilford Press, New York)

Brown M P, 2000 Closet Space (Routledge, London)

Butler J, 1990 Gender Trouble: Feminism and the Subversion of Identity (Routledge, London)

Butler J, 1993 Bodies that Matter (Routledge, London)

Chauncey G, 1995 Gay New York: The Making of the Gay Male World, 1890 - 1940 (Flamingo, London)

Comstock G, 1991 Violence Against Lesbians and Gay Men (Columbia University Press, New York)

Conrad K, 1998, "Women troubles, queer troubles: gender, sexuality and the politics of selfhood in the construction of the Irish State", in Reclaiming Gender: Transgressive Identities in Modern Ireland Eds M Cohen, N Curtin (St Martin's Press, New York) pp 53-68

Conrad K, 2001, "Queer treasons: homosexuality and Irish national identity" Cultural Studies 15 $124-137$

Davis T, 1995, "The diversity of queer politics and the redefinition of sexual identity and community in urban spaces", in Mapping Desire: Geographies of Sexuality Eds D Bell, G Valentine (Routledge, London) pp 284-303

Disability Discrimination Act, 1995 Public General Acts - Elizabeth II chapter 50 (HMSO, London)

Doherty P, Poole M, 1995 Ethnic Residential Segregation in Belfast (Centre for the Study of Conflict, University of Ulster, Coleraine)

Equality (Disability, etc) (Northern Ireland) Order, 2000 (The Stationery Office, Belfast)

Fair Employment and Treatment (Northern Ireland) Order, 2000 (The Stationery Office, Belfast)

Forrest B, 1995, "West Hollywood as symbol: the significance of place in the construction of a gay identity" Environment and Planning D: Society and Space 13133 - 157

Foucault M, 1978 The History of Sexuality. Volume 1: The Will to Knowledge (Penguin Books, Harmondsworth, Middx)

Foucault M, 1984a The History of Sexuality. Volume 2: The Use of Pleasure (Penguin Books, Harmondsworth, Middx) 
Foucault M, 1984b The History of Sexuality. Volume 3: The Care of the Self (Penguin Books, Harmondsworth, Middx)

Herek G M, Berrill K T (Eds), 1992 Hate Crimes: Confronting Violence Against Lesbians and Gay Men (Sage, Newbury Park, CA)

Hubbard P, 1999 Sex and the City: Geographies of Prostitution in the Urban West (Ashgate, Aldershot, Hants)

Ingram G B, Bouthillette A-M, Retter Y, 1997 Queers in Space: Communities, Public Places, Sites of Resistance (Bay Press, San Francisco, CA)

Jagose A, 1996 Queer Theory: An Introduction (New York University Press, New York)

Johnston L, Valentine G, 1995, "Wherever I lay my girlfriend, that's my home: the performance and surveillance of lesbian identities in domestic environments", in Mapping Desire Eds D Bell, G Valentine (Routledge, London) pp $99-113$

Kaiser C, 1997 The Gay Metropolis (Phoenix, London)

Keith M, Pile S, 1993, "Introduction, part 1: the politics of place", in Place and the Politics of Identity Eds M Keith, S Pile (Routledge, London) pp 1-22

Kitchin R, 2002, "Sexing the city: the sexual production of space in Belfast, Manchester and San Francisco" City 6 205-218

Kitchin R, Tate N, 2000 Conducting Research in Human Geography: Theory, Methodology and Practice (Prentice Hall, Harlow, Essex)

Knopp L, 1990, "Some theoretical implications of gay involvement in an urban land market" Political Geography Quarterly 9337 - 352

Knopp L, 1995, "Sexuality and urban space: a framework for analysis", in Mapping Desire: Geographies of Sexuality Eds D Bell, G Valentine (Routledge, London) pp 149 - 161

Lauria M, Knopp L, 1985, "Towards an analysis of the role of gay communities in the urban renaissance" Urban Geography $6152-169$

Law L, 2000 Sex Work in Southeast Asia: The Place of Desire in the Time of AIDS (Routledge, London)

Leap W L (Ed.), 1999 Public Sex/Gay Space (Between Men - Between Women: Lesbian and Gay Studies) (Columbia University Press, New York)

Lysaght K, 2002, "Dangerous friends and deadly foes-performances of masculinity in the divided city" Irish Geography 35 51-62

McClenaghan B, 1995, "Letters from a gay republican: H-Block 5", in Lesbian and Gay Visions of Ireland Eds I O'Carroll, E Collins (Cassell, London) pp 122-130

McDowell L, 1997 Capital Culture: Gender at Work in the City (Blackwell, Oxford)

Moran L, Skeggs B, Tyrer P, Corteen K, 2001, "Property, boundary, exclusion: making sense of hetero-violence in safer spaces" Social and Cultural Geography 2 407-420

Mort F, 1996 Cultures of Consumption (Routledge, London)

Mulholland M, 1995, "Ghetto-blasting", in Lesbian and Gay Visions of Ireland Eds I O'Carroll, E Collins (Cassell, London) pp $131-137$

Myslik W D, 1996, "Renegotiating the social/sexual identities of places: gay communities as safe havens or sites of resistance", in BodySpace Ed. N Duncan (Routledge, London) pp $156-169$

Northern Ireland Act, 1998 Public General Acts - Elizabeth II chapter 47 (The Stationery Office, London)

Patton C, Sanchez-Eppler B (Eds), 2000 Queer Diasporas (Duke University Press, Durham, NC)

Peake L, 1993, “'Race' and sexuality: challenging the patriarchal structuring of urban social space" Environment and Planning D: Society and Space $11415-432$

Phillips R, Watt D, Shuttleton D (Eds), 2000 De-centring Sexualities: Politics and Representation Beyond the Metropolis (Routledge, London)

Protection from Harassment Act, 1997 Public General Acts - Elizabeth II chapter 40 (The Stationery Office, London)

Quilley S, 1997, “Constructing Manchester's 'new urban village': gay space in the entrepreneurial city", in Queers in Space: Communities, Public Places, Sites of Resistance Eds G B Ingram, A-M Bouthillette, Y Retter (Bay Press, San Francisco, CA) pp 275-292

Quinn V, 2000, "On the borders of allegiance: identity politics in Ulster", in De-centring Sexualities: Politics and Representation Beyond the Metropolis Eds R Phillips, D Watt, D Shuttleton (Routledge, London) pp 258-277

Race Relations (Northern Ireland) Order, 1997 (The Stationery Office, Belfast) 
Rothenburg T, 1995, “'And she told two friends': lesbians creating urban social space”, in Mapping Desire: Geographies of Sexuality Eds D Bell, G Valentine (Routledge, London) pp $165-181$

Rubin G, 1989, "Thinking sex: notes for a radical theory of the politics of sexuality", in Pleasure and Danger: Exploring Female Sexuality Ed. C Vance (Pandora, London)

Saraga E, 1998, "Abnormal, unnatural and immoral? The social construction of sexualities", in Embodying the Social: Constructions of Difference Ed. E Sarage (Routledge, London) pp $139-188$

Sex Discrimination (Gender Reassignment) Regulations (Northern Ireland), 1999 (The Stationery Office, Belfast)

Stryker S, van Buskirk J, 1996 Gay by the Bay: A History of Queer Culture in the San Francisco Bay Area (Chronicle Books, San Francisco, CA)

Valentine G, 1993, "(Hetero)sexing space: lesbian perceptions and experiences of everyday spaces" Environment and Planning D: Society and Space $11395-413$

Valentine G 1996, “(Re)negotiating the 'heterosexual street': lesbian productions of space”, in BodySpace Ed. N Duncan (Routledge, London) pp 146-155

Valentine G (Ed.), 2000 From Nowhere to Everywhere: Lesbian Geographies (Harrington Park Press, New York)

Whittle S (Ed.), 1994 The Margins of the City: Gay Men's Urban Lives (Arena, Aldershot, Hants) 